\title{
Maito-liharoturisteytyssonnien ja -hiehojen kasvu- ja teurasominaisuudet
}

\author{
Arto Huuskonen ${ }^{1)}$, Maiju Pesonen ${ }^{1)}$, Maarit Hyrkäs ${ }^{2)}$, Hilkka Kämäräinen ${ }^{3)}$ ja Risto Kauppinen ${ }^{3)}$ \\ ${ }^{1)}$ Maa- ja elintarviketalouden tutkimuskeskus, Kotieläintuotannon tutkimus, Tutkimusasemantie 15, \\ 92400 Ruukki,arto.huuskonen@mtt.fi, maiju.pesonen@mtt.fi \\ ${ }^{2)}$ Maa- ja elintarviketalouden tutkimuskeskus, Kotieläintuotannon tutkimus, Halolantie 31A, 71750 \\ Maaninka, maarit.hyrkas@mtt.fi \\ ${ }^{3)}$ Savonia-ammattikorkeakoulu, PL 72, Haukisaarentie 2, 74101 Iisalmi, \\ hilkka.kamarainen@savonia.fi, risto.kauppinen@savonia.fi
}

\section{Tiivistelmä}

Tutkimuksella selvitettiin risteytyseläinten kasvu- ja teurasominaisuuksia puhtaisiin maitorodun nautoihin verrattuna. Tutkimusaineistona käytettiin teurastamoilta saatua naudan ruhojen teurasaineistoa, johon yhdistettiin ProAgria Maatalouden Laskentakeskuksen kautta saatu eläimen emän rotutieto. Teurastamoilta saatua aineistoa oli käytössä HK Agri Oy:Itä ja Snellman Lihanjalostus Oy:ltä vuodesta 2007 lähtien, A-Tuottajat Oy:ltä vuodesta 2008 lähtien ja Saarioinen Lihanjalostus Oy:ltä vuodesta 2010 lähtien. Hiehojen osalta alle 8 kk:n (alle 240 pv) ja yli 20 kk:n ikäiset (yli 600 pv) eläimet jätettiin datasta pois. Vastaavasti sonnien osalta alle 12 kk:n (alle 365 pv) ja yli 24 kk:n ikäiset (yli 730 pv) eläimet jätettiin datasta pois. Rajausten jälkeen tutkimusaineisto sisälsi 268895 teurastettua sonnia ja 32410 teurashiehoa.

Puhtailla ayrshire-rotuisilla (ay) sonneilla keskimääräinen kasvatusaika oli aineistossa 592 vrk, nettokasvu $532 \mathrm{~g} / \mathrm{pv}$, teuraspaino $330 \mathrm{~kg}$, ruhojen lihakkuusluokka 4,7 (O-luokka) ja rasvaisuusluokka 2,4. Puhtaiden holstein-friisiläisten (fr) vastaavat tulokset olivat kasvatusaika 587 vrk, nettokasvu 542 g/pv, teuraspaino $333 \mathrm{~kg}$, lihakkuusluokka 4,1 (O-) ja rasvaisuusluokka 2,4. Ay- ja fr-rotujen sonnit erosivat merkitsevästi $(\mathrm{p}<0,001)$ toisistaan kaikkien muiden parametrien paitsi ruhon rasvaisuuden osalta. Liharoturisteytysten käyttö paransi selkeästi sonnien päiväkasvua $(\mathrm{p}<0,001)$, lisäsi teuraspainoa $(\mathrm{p}<0,001)$ ja paransi ruhojen lihakkuutta $(\mathrm{p}<0,001)$ sekä ay- että fr-rodulla. Kaikilla testatuilla liharoturisteytyksillä [aberdeen angus (ab), hereford (hf), limousin (li), charolais (ch), simmental (si), blonde d'Aquitaine (ba)] oli samansuuntainen vaikutus edellä mainittuihin ominaisuuksiin. Suurimmat teuraspainot ja korkeimmat nettokasvut saavutettiin ch-, si- ja ba-rodulla risteytettäessä. Ruhojen lihakkuus puolestaan parani eniten ba-, li- ja ch-rodun risteytyksiä käytettäessä. Ruhon rasvaisuuden osalta risteyttäminen ba-rodulla vähensi $(\mathrm{p}<0.001)$ ruhojen rasvaisuutta puhtaisiin maitorotusonneihin verrattuna. Sen sijaan muilla liharoduilla risteyttäminen näytti lisäävän $(\mathrm{p}<0.001)$ ruhojen rasvaisuutta puhtaisiin ay- ja fr-sonneihin verrattuna. Sekä ruhojen lihakkuuden että rasvaisuuden osalta on kuitenkin huomioitava myös teuraspainon vaikutus, sillä teuraspainon kasvu paransi ruhojen lihakkuutta ja lisäsi rasvaisuutta kaikilla roduilla ja rotuyhdistelmillä. Samoin nettokasvun lisääntyminen paransi ruhojen lihakkuutta ja lisäsi rasvaisuutta kaikilla roduilla ja rotuyhdistelmillä.

Teurashiehojen osalta tulokset olivat hyvin samansuuntaiset kuin sonneilla. Liharoturisteytysten käyttö paransi teurashiehojen päiväkasvua $(\mathrm{p}<0,001)$, lisäsi teuraspainoa $(\mathrm{p}<0,001)$ ja paransi ruhojen lihakkuutta $(\mathrm{p}<0,001)$ sekä ay- että fr-rodulla. Korkeammista teuraspainoista huolimatta ba-rodulla risteyttäminen vähensi $(\mathrm{p}<0.001)$ ruhojen rasvaisuutta puhtaaseen maitorotuun verrattuna. Sen sijaan muilla liharoduilla risteyttämien näytti lisäävän $(\mathrm{p}<0.001)$ ruhojen rasvaisuutta myös hiehoilla. Tulosten perusteella liharotusiemennysten käyttöä maitotiloilla lisäämällä on mahdollista lisätä naudanlihantuotannon tehokkuutta maidontuotantotiloilta peräisin olevien risteytysvasikoiden kautta.

Asiasanat: naudanlihantuotanto, rodut, liharoturisteytykset, ruhon laatu, kasvu, ruhon lihakkuus, ruhon rasvaisuus 


\section{Johdanto}

Liharotusiemennysten käyttömäärää suomalaisilla maitotiloilla on suositeltu pidettävän 10-20 prosentin tasolla. Käytännössä toteutuma on kuitenkin ollut viime vuosina vain noin 5-6 prosentin luokkaa. Liharotusiemennysten osuus voitaisiin kuitenkin uusia tekniikoita hyödyntäen nostaa ainakin 25 prosenttiin siemennyksistä. Käytännön jalostussuunnittelussa lypsykarjan perinnöllisesti parhaille lehmille (n. $40 \%$ ) suositellaan valiosonnisiemennystä, keskitason lehmille (n. $40 \%$ ) nuorsonnisiemennystä ja heikoimmille lehmille liharotusiemennystä, alkion vastaanottoa tai poistoa.

Karjakoon kasvu ja siittiöiden sukupuolilajittelu mahdollistavat kuitenkin vielä tehokkaamman karjansisäisen jalostussuunnittelun. Lisäksi jalostusmenetelmät ovat radikaalisti muuttumassa genomiseen jalostusvalintaan siirryttäessä. Seuraava merkittävä edistyminen karja-aineksen tason kohottamisessa voidaan tehdä nimenomaan genomisia jalostusmenetelmiä käyttämällä. Sonnien valinta tehdään tulevaisuudessa geenimerkkien perusteella jo hyvin nuorena, jolloin nuorsonnisiemennysten tarve vähenee radikaalisti. Myös lehmät voidaan valita nuorina samoin perustein ja yhtä luotettavasti kuin sonnit. Pohjois-Savossa onkin käynnistynyt Savonia-ammattikorkeakoulun hallinnoima MAILI-hanke, jonka tavoitteena on lisätä liharotusiemennysten osuutta lypsykarjatiloilla. Toimenpiteellä voitaisiin tehostaa lehmävalintaa ja edistää eläinaineksen paranemista maidontuotannossa. Samalla olisi mahdollista lisätä naudanlihantuotannon tehokkuutta risteytysvasikoiden kautta.

Suomalaiset naudanlihantuotantotutkimukset on aloitettu silloisessa Maatalouden tutkimuskeskuksessa vuonna 1960 (Ruohomäki 1976). Jo alkuvuosina kokeiltiin Brown Swiss -risteytystä, jolla pienessä kokeessa saatiin noin $10 \%$ lisäys ayrshiren ja suomenkarjan kasvutuloksiin ja teuraspainoon. Uudenmaan ja Kymen keinosiemennysyhdistyksen kokeessa charolais-risteytykset menestyivät erittäin hyvin, hereford-risteytykset olivat hieman parempia kuin puhdas ayrshire, kun taas aberdeen angus-risteytykset jäivät muita heikommiksi (Ruohomäki 1976). Viimeisen 25 vuoden aikana Suomessa ei ole kuitenkaan tehty kasvatuskokeita eläinaineksella, joka pohjautuisi lypsylehmien ja liharotuisten sonnien jälkeläisiin. Naudanlihantuotannon edistämisprojektin aineistot 1990-luvulla perustuivat hereford-ayrshire ja limousin-ayrshire -rotuisiin emolehmiin ja niiden jälkeläisten kasvatuskokeisiin (Manninen ym. 1994). Eläinjalostus on edennyt merkittävästi 20-30 vuoden aikana, joten MAILIhankkeessa tehtävien laskelmien pohjaksi tarvittiin tietoa Suomessa nykyisin käytössä olevan eläinaineksen kasvu- ja teurasominaisuuksista. Tässä artikkelissa esiteltävässä tutkimusosiossa selvitettiin risteytyseläinten kasvu- ja teurasominaisuuksia puhtaisiin maitorodun nautoihin verrattuna.

\section{Aineisto ja menetelmät}

Tutkimusaineistona oli teurastamoilta saatu naudan ruhojen teurasaineisto, johon yhdistettiin ProAgria Maatalouden Laskentakeskuksen kautta saadut rotutiedot. Teurastamoaineistoa oli käytössä Hk Agri Oy:Itä ja Snellman Lihanjalostus Oy:Itä vuodesta 2007 lähtien, A-Tuottajat Oy:ltä vuodesta 2008 lähtien ja Saarioinen Lihanjalostus Oy:Itä vuodesta 2010 lähtien. Yhdistetyssä datassa olivat mukana seuraavat tiedot: eläimen syntymätunnus, teurastuspäivä, teuraspaino, teurastuksessa hylättyjen osien paino, ruhon laatuluokka, ruhon rasvaisuusluokka, eläimen syntymäaika, eläimen sukupuoli, eläimen rotukoodi, eläimen emän rotukoodi ja eläimen isän rotukoodi. Teurasruhot oli teurastamoissa punnittu ja luokiteltu EUROP - luokituksen mukaisesti. Nettokasvutulosten laskemiseksi dataan lisättiin uutena muuttujana eläimen lihapaino syntyessä (alkupaino). Tämä lisättiin oletusarvona siten, että alkupainoksi määritettiin sonnivasikalle $16 \mathrm{~kg}$ ja lehmävasikalle $15,2 \mathrm{~kg}$. Vastaavia arvioita A-Tuottajat Oy käyttää päivittäisessä työssään (Herva ym. 2009). Nettokasvu laskettiin teuraspainon ja kokeen alun lihapainon erotuksena jaettuna kasvatuspäivillä.

Datan käsittelyn ensimmäisessä vaiheessa teurasaineistosta jätettiin pois lypsy- ja emolehmät sekä sekä eläimet, jotka eivät olleet lypsylehmien jälkeläisiä. Teurashiehojen osalta alle 8 kk:n (alle 240 pv) ja yli 20 kk:n ikäisenä (yli 600 pv) teurastetut eläimet jätettiin myös datasta pois. Vastaavasti sonnien osalta alle 12 kk:n (alle 365 pv) ja yli 24 kk:n (yli 730 pv) ikäisenä teurastetut eläimet rajattiin pois. Näiden rajausten jälkeen tutkimusaineisto sisälsi 268895 teurastettua sonnia ja 32410 teurashiehoa.

Edellä mainittujen rajausten jälkeen teurasaineistosta eriteltiin puhtaat ayrshire (ay) ja holsteinfriisiläis (fr) eläimet. Eläimen katsottiin edustavan kyseistä rotua, jos sen molemmat vanhemmat olivat ProAgria Maatalouden Laskentakeskuksen aineistossa luokiteltu ao. rodun edustajiksi. Niin ikään eriteltiin maito-liharoturisteytykset roduittain eli teuraseläimet, joiden emä oli joko ay- tai fr-rotua ja eläimen isärotuna oli käytetty liharotuista sonnia. Puhtaita ay-rotuisia sonneja lopulliseen data- 
aineistoon jäi yhteensä $164812 \mathrm{kpl}$ ja puhtaita fr-sonneja puolestaan $87323 \mathrm{kpl}$. Ayliharoturisteytyssonneja lopullisessa aineistossa oli seuraavasti ayxaberdeen angus (ab) $2329 \mathrm{kpl}$, ay $\times$ hereford (hf) $782 \mathrm{kpl}$, ayxlimousin (li) $5293 \mathrm{kpl}$, ay $\times$ charolais (ch) $1044 \mathrm{kpl}$, ay $\times$ simmental (si) $1270 \mathrm{kpl} \mathrm{ja}$ ayxblonde d'Aquitaine (ba) $1466 \mathrm{kpl}$. Vastaavasti fr- liharoturisteytyssonnien kappalemäärät olivat: fr×ab $783 \mathrm{kpl}$, fr×hf $349 \mathrm{kpl}$, fr×li $1691 \mathrm{kpl}$, fr×ch $562 \mathrm{kpl}$, fr×si $570 \mathrm{kpl}$ ja fr×ba 621 $\mathrm{kpl}$.

Puhtaita ay-rotuisia teurashiehoja lopulliseen data-aineistoon jäi yhteensä $14221 \mathrm{kpl}$ ja puhtaita fr-hiehoja $6348 \mathrm{kpl}$. Ay-liharoturisteytyshiehoja lopullisessa aineistossa oli seuraavasti ay $\times$ aberdeen angus (ab) $1626 \mathrm{kpl}$, ayxhf $487 \mathrm{kpl}$, ayxli $3699 \mathrm{kpl}$, ayxch $802 \mathrm{kpl}$, ayxsi $827 \mathrm{kpl} \mathrm{ja} \mathrm{ay \times ba} 1136 \mathrm{kpl}$. Vastaavasti fr- liharoturisteytyshiehojen kappalemäärät olivat: fr×ab $531 \mathrm{kpl}$, fr×hf $186 \mathrm{kpl}$, fr×li $1249 \mathrm{kpl}$, fr×ch $438 \mathrm{kpl}$, fr×si $393 \mathrm{kpl} \mathrm{ja} \mathrm{fr \times ba} 467 \mathrm{kpl}$.

Tilastollisena käsittelynä tuloksille tehtiin varianssianalyysi SAS 9.2. -ohjelmiston MIXEDproseduurilla. Rotujen välisten erojen tilastollinen merkitsevyys testattiin pareittaisilla vertailuilla Dunnetin -testillä. Testillä vertailtiin puhtaiden ay-sonnien tuloksia erikseen kuhunkin ay $\times$ liharotu sonnien tuloksiin. Vastaavat vertailut eri liharoturisteytyksiin tehtiin fr-sonneille, ay-hiehoille ja frhiehoille. Lisäksi testattiin puhtaiden ay- ja fr-rotuisten eläinten keskinäiset erot kasvu- ja teurasominaisuuksissa.

\section{Tulokset ja tulosten tarkastelu Sonnien kasvu- ja teurastulokset}

Puhtailla ayrshire-rotuisilla (ay) sonneilla keskimääräinen kasvatusaika oli aineistossa 592 vrk, nettokasvu $532 \mathrm{~g} / \mathrm{pv}$, teuraspaino $330 \mathrm{~kg}$, ruhojen lihakkuusluokka 4,7 (O-luokka) ja rasvaisuusluokka 2,4. Puhtaiden holstein-friisiläisten (fr) vastaavat tulokset olivat kasvatusaika 587 vrk, nettokasvu 542 g/pv, teuraspaino $333 \mathrm{~kg}$, lihakkuusluokka 4,1 (O-) ja rasvaisuusluokka 2,4. Ay- ja fr-rotujen sonnit erosivat merkitsevästi $(\mathrm{p}<0,001)$ toisistaan kaikkien muiden parametrien paitsi ruhon rasvaisuuden osalta. Käytännön kannalta merkittävin ero puhtaiden maitorotuisten sonnien osalta näkyi ruhojen lihakkuudessa. Ay-sonnit luokittuivat keskimäärin $15 \%$ paremmin kuin fr-sonnit. Nettokasvutuloksissa ero oli vajaa $2 \%$ fr-sonnien hyväksi. Verrattuna meillä aikaisemmin käytettyyn friisiläisrotuiseen eläinainekseen nykyisen holstein-friisiläisen eläinaineksen kasvu- ja lihantuotanto-ominaisuudet ovat heikompia. Esimerkiksi vielä 1980-luvun loppupuolella friisiläis-sonnit kasvoivat noin 7 \% paremmin kuin ayrshire-sonnit (Lampinen 1987).

Liharoturisteytysten käyttö paransi sonnien kasvua, lisäsi teuraspainoa ja paransi ruhojen lihakkuutta sekä ay- että hol-rodulla (Taulukot 1 ja 2). Kaikilla testatuilla liharoturisteytyksillä oli samansuuntainen vaikutus edellä mainittuihin ominaisuuksiin. Suurimmat teuraspainot ja korkeimmat nettokasvut saavutettiin ch-, si- ja ba-roduilla risteytettäessä.

Ruhojen lihakkuus parani eniten ba-, li- ja ch-rodun risteytyksiä käytettäessä. Ruhojen lihakkuus näytti paranevan liharoturisteytyksen ansiosta enemmän fr- kuin ay-rodun sonneilla. Ruhon rasvaisuuden osalta risteyttäminen ba-rodulla vähensi ruhojen rasvaisuutta puhtaisiin maitorotusonneihin verrattuna. Sen sijaan muilla liharoduilla risteyttäminen näytti hieman lisäävän ruhojen rasvaisuutta puhtaisiin ay- ja hol-sonneihin verrattuna. Sekä ruhojen lihakkuuden että rasvaisuuden osalta on kuitenkin huomioitava myös teuraspainon vaikutus, sillä teuraspainon kasvu paransi ruhojen lihakkuutta ja lisäsi rasvaisuutta kaikilla testatuilla roduilla ja rotuyhdistelmillä. Samoin nettokasvun lisääntyminen paransi ruhojen lihakkuutta ja lisäsi rasvaisuutta kaikilla roduilla ja rotuyhdistelmillä.

Varsinkin puhtailla maitoroduilla sekä keskikokoisten liharotujen ( $\mathrm{ab}, \mathrm{hf}$ ) ja maitorotujen risteytyssonneilla ruhot rasvoittuvat nopeasti teuraspainojen ylittäessä $350 \mathrm{~kg}$. Myös rotuyhdistelmien välillä erot olivat selkeät. Keskimääräinen rasvaisuusluokkaan 3 sijoittuva puhdasrotuinen ay-sonni painoi data-aineistossa $348 \mathrm{~kg}$. Vastaavat keskimääräiset teuraspainot rasvaisuusluokassa 3 olivat risteytyssonneilla 354 (hf), 359 (ab), 383 (li), 392 (si), 395 (ba) ja 402 (ch) (Kuva 1). Kuvasta 1 ilmenee, että

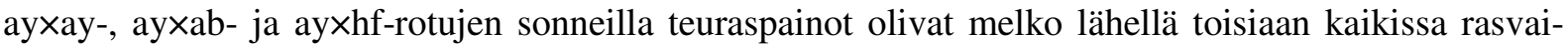
suusluokissa. Edellä mainitut rotuyhdistelmät erosivat selkeästi ay $\times b a-$, ay $\times c h-$, ay $\times 1 i-$ ja ay $\times s i-$ rotujen sonneista, jotka voitiin kasvattaa selkeästi suurempiin teuraspainoihin kussakin rasvaisuusluokassa.

Kun tarkasteltiin eläinten keskimääräistä teuraspainoa erikseen kussakin lihakkuusluokassa, esille nousivat erityisesti ba- ja li-rotujen hyvät lihakkuusominaisuudet. Näiden rotujen risteytyseläimet saavuttivat korkeamman lihakkuusluokan selvästi muita rotuja alhaisemmassa teuraspainossa. 
Esimerkiksi lihakkuusluokkaan R- luokittuva ay×ba -sonni painoi keskimäärin $370 \mathrm{~kg}$ ja ay×li -sonni vastaavasti $371 \mathrm{~kg}$. Muilla rotuyhdistelmillä R- luokittuminen saavutettiin keskimäärin seuraavissa teuraspainoissa: ay (398), ay×ab (384), ay×hf (390), ayxsi (402), ay×ch (387).

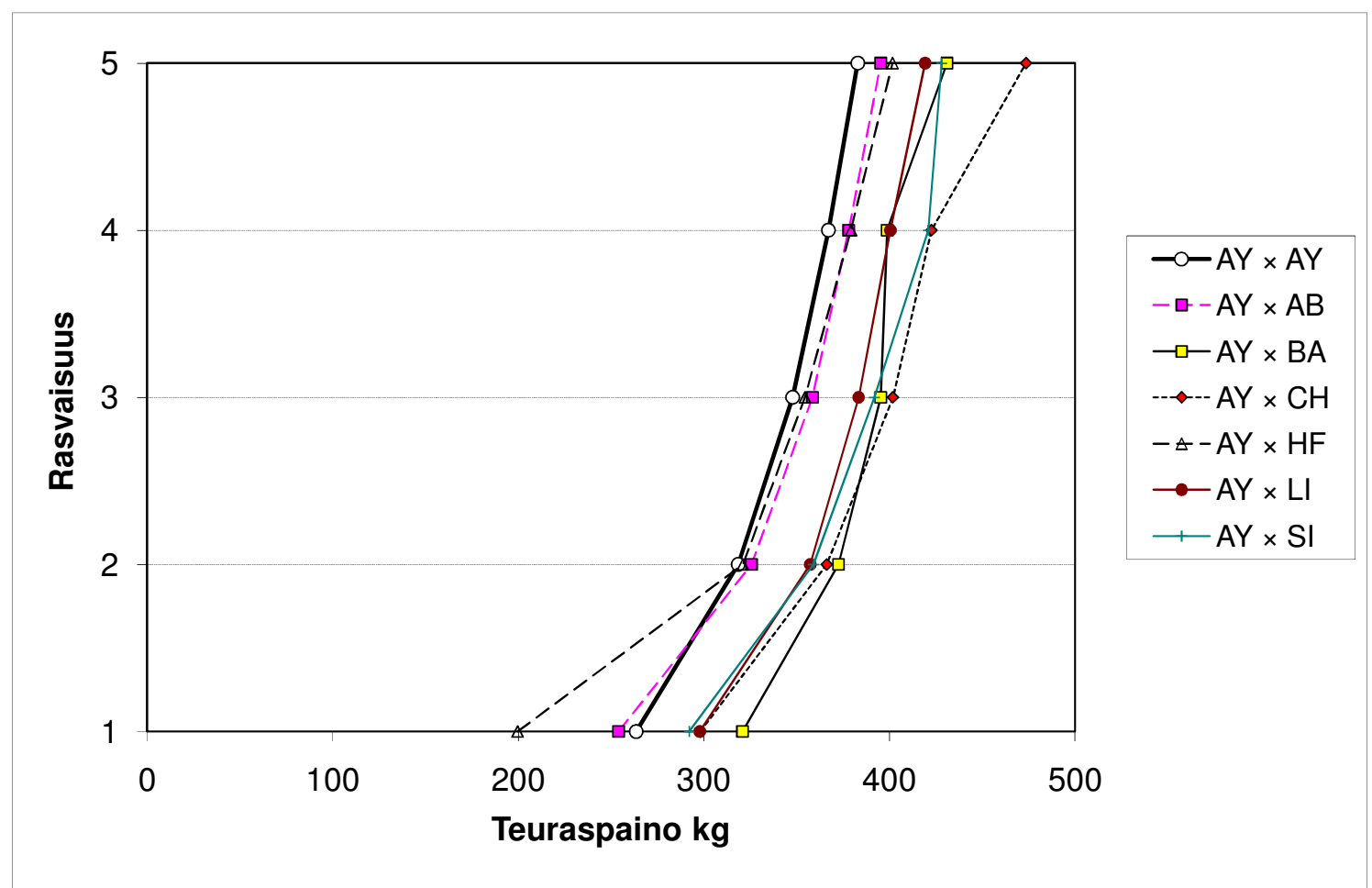

Kuva 1. Ay-risteytyssonnien ruhojen rasvaisuusluokka teuraspainon mukaan eri rotuyhdistelmillä.

\section{Hiehojen kasvu- ja teurastulokset}

Puhtailla ay-hiehoilla keskimääräinen kasvatusaika oli aineistossa 492 vrk, nettokasvu $381 \mathrm{~g} / \mathrm{pv}$, teuraspaino $202 \mathrm{~kg}$, ruhojen lihakkuusluokka 3,4 $(\mathrm{P}+)$ ja rasvaisuusluokka 2,7. Puhtaiden fr-hiehojen vastaavat tulokset olivat: kasvatusaika 486 vrk, nettokasvu $399 \mathrm{~g} / \mathrm{pv}$, teuraspaino $208 \mathrm{~kg}$, lihakkuusluokka 3,0 $(\mathrm{P}+)$ ja rasvaisuusluokka 2,7. Ay- ja fr-rotujen hiehot erosivat merkitsevästi $(\mathrm{p}<0,001)$ toisistaan kaikkien muiden parametrien paitsi ruhon rasvaisuuden osalta. Merkittävin ero puhtaiden maitorotuisten hiehojenkin osalta näkyi ruhojen lihakkuudessa. Ay-hiehot luokittuivat keskimäärin $13 \%$ paremmin kuin fr-hiehot. Nettokasvutuloksissa ero oli vajaa $5 \%$ fr-hiehojen hyväksi.

Teurashiehojen osalta tulokset olivat hyvin samansuuntaiset kuin sonneilla. Liharoturisteytysten käyttö paransi teurashiehojen nettokasvua, lisäsi teuraspainoa ja paransi ruhojen lihakkuutta sekä ayettä fr-rodulla (Taulukot 3 ja 4). Nettokasvutuloksissa liharoturisteytyksillä saavutetut hyödyt vaihtelivat 11 (fr×ab) ja 28 (ay×ch) prosentin välillä. Ruhojen lihakkuus parani peräti 35 (ay×hf) - 90 (fr×ba) prosenttia puhtaaseen maitorodun hiehoon verrattuna.

Korkeammista teuraspainoista huolimatta ba-rodulla risteyttäminen vähensi ruhojen rasvaisuutta myös teurashiehoilla puhtaaseen maitorotuun verrattuna. Sen sijaan muilla liharoduilla risteyttäminen näytti korkeammista teuraspainoista johtuen lisäävän ruhojen rasvaisuutta myös hiehoilla.

Myös hiehoilla teuraspainon suhde ruhon rasvoittumiseen tuli aineistosta selkeästi esille, ja hiehoillakin rotuyhdistelmien välillä erot olivat selkeät. Keskimääräinen rasvaisuusluokkaan 3 sijoittuva puhdasrotuinen ay-hieho painoi data-aineistossa $214 \mathrm{~kg}$. Vastaavat keskimääräiset teuraspainot rasvaisuusluokassa 3 olivat risteytyshiehoilla 211 (ab), 220 (hf), 235 (si), 237 (li), 247 (ch) ja 251 (ba). 
Taulukko 1. Puhtaiden ayrshiresonnien (ay) sekä ay $\times$ liharoturisteytyssonnien kasvu- ja teurastulokset roduittain $(a b=$ aberdeen angus, ba = blonde d'Aquitaine, ch $=$ charolais, $\mathrm{hf}=$ hereford, $\mathrm{li}=$ limousin, $\mathrm{si}=$ simmental $)$

\begin{tabular}{|c|c|c|c|c|c|c|c|c|c|c|c|c|c|c|c|}
\hline & \multicolumn{7}{|c|}{ Rotu } & \multirow[b]{2}{*}{ SEM $^{1}$} & \multicolumn{7}{|c|}{ Tilastollinen merkitsevyys $^{2}$} \\
\hline & ayxay & ay $\times a b$ & ay $\times$ ba & ayxch & ay $\times$ hf & ay $\times$ li & ay $\times$ si & & p-arvo & ayxab & ay $\times$ ba & ayxch & ay $\times$ hf & ayxli & ay $\times$ si \\
\hline Eläinmäärä, kpl & 164812 & 2329 & 1466 & 1044 & 782 & 5293 & 1270 & & & & & & & & \\
\hline Kasvatusaika, pv & 592 & 596 & 583 & 586 & 588 & 590 & 583 & 2,2 & $<0,001$ & $*$ & $* * *$ & $*$ & & & $* * *$ \\
\hline Nettokasvu, g/pv & 532 & 576 & 616 & 629 & 580 & 605 & 628 & 2,8 & $<0,001$ & $* * *$ & $* * *$ & $* * *$ & $* * *$ & $* * *$ & $* * *$ \\
\hline Teuraspaino, kg & 330 & 357 & 374 & 383 & 356 & 372 & 381 & 1,7 & $<0,001$ & $* * *$ & $* * *$ & $* * *$ & $* * *$ & $* * *$ & $* * *$ \\
\hline Lihakkuus $^{3}$ & 4,7 & 6,0 & 7,4 & 7,1 & 5,8 & 7,3 & 6,4 & 0,04 & $<0,001$ & $* * *$ & $* * *$ & $* * *$ & $* * *$ & $* * *$ & $* * *$ \\
\hline Rasvaisuus 4 & 2,4 & 3,1 & 2,2 & 2,5 & 3,2 & 2,6 & 2,7 & 0,02 & $<0,001$ & $* * *$ & $* * *$ & $* * *$ & $* * *$ & $* * *$ & $* * *$ \\
\hline
\end{tabular}

${ }^{1}$ SEM = Keskiarvon keskivirhe.

${ }^{2}$ Pareittaiset vertailut on tehty Dunnetin-testillä. Testillä on testattu poikkeaako kyseisen risteytyksen tulos puhtaan ayxay-eläimen tuloksesta.

$* * *(\mathrm{p}<0,001), * *(\mathrm{p}<0,01), *(\mathrm{p}<0,05)$ ja o $(\mathrm{p}<0,10)$

${ }^{3}$ Lihakkuus: EUROP-luokitus ( 1 = heikoin, 15 = paras). 1=P-, 2=P, 3=P+, 4=O-, 5=O, 6=O+, 7=R-, 8=R, 9=R+, 10=U-, 11=U, 12=U+, 13=E-, 14=E, 15=E+.

${ }^{4}$ Rasvaisuus: EUROP-luokitus ( 1 = rasvaton, 5 = erittäin rasvainen).

Taulukko 2. Puhtaiden holstein-friisiläissonnien (fr) sekä fr $\times$ liharoturisteytyssonnien kasvu- ja teurastulokset roduittain $(\mathrm{ab}=\mathrm{aberdeen}$ angus, ba $=$ blonde d'Aquitaine, $\mathrm{ch}=$ charolais, $\mathrm{hf}=$ hereford, $\mathrm{li}=$ limousin, $\mathrm{si}=$ simmental $)$.

\begin{tabular}{|c|c|c|c|c|c|c|c|c|c|c|c|c|c|c|c|}
\hline & \multicolumn{7}{|c|}{ Rotu } & SEM $^{1}$ & \multicolumn{7}{|c|}{ Tilastollinen merkitsevyys $^{2}$} \\
\hline Kasvatusaika, pv & 587 & 592 & 582 & 575 & 592 & 586 & 582 & 3,4 & $<0,001$ & $*$ & $*$ & $* * *$ & & & $*$ \\
\hline Teuraspaino, kg & 333 & 357 & 379 & 387 & 366 & 372 & 383 & 2,6 & $<0,001$ & $* * *$ & $* * *$ & $* * *$ & $* * *$ & $* * *$ & $* * *$ \\
\hline Lihakkuus ${ }^{3}$ & 4,1 & 5,8 & 7,3 & 7,0 & 5,8 & 7,1 & 6,3 & 0,05 & $<0,001$ & $* * *$ & $* * *$ & $* * *$ & $* * *$ & $* * *$ & $* * *$ \\
\hline Rasvaisuus $^{4}$ & 2,4 & 3,0 & 2,1 & 2,5 & 3,2 & 2,5 & 2,7 & 0,03 & $<0,001$ & $* * *$ & $* * *$ & $* * *$ & $* * *$ & $* * *$ & $* * *$ \\
\hline
\end{tabular}

${ }^{1}$ SEM = Keskiarvon keskivirhe.

${ }^{2}$ Pareittaiset vertailut on tehty Dunnetin-testillä. Testillä on testattu poikkeaako kyseisen risteytyksen tulos puhtaan fr $\times f r-e l a ̈ i m e n ~ t u l o k s e s t a$.

$* * *(\mathrm{p}<0,001), * *(\mathrm{p}<0,01), *(\mathrm{p}<0,05)$ ja o $(\mathrm{p}<0,10)$.

${ }^{3}$ Lihakkuus: EUROP-luokitus $(1=$ heikoin, $15=$ paras $) .1=\mathrm{P}-, 2=\mathrm{P}, 3=\mathrm{P}+, 4=\mathrm{O}-, 5=\mathrm{O}, 6=\mathrm{O}+, 7=\mathrm{R}-, 8=\mathrm{R}, 9=\mathrm{R}+, 10=\mathrm{U}-, 11=\mathrm{U}, 12=\mathrm{U}+, 13=\mathrm{E}-, 14=\mathrm{E}, 15=\mathrm{E}+$.

${ }^{4}$ Rasvaisuus: EUROP-luokitus ( 1 = rasvaton, 5 = erittäin rasvainen). 
Taulukko 3. Puhtaiden ayrshirehiehojen (ay) sekä ay $\times$ liharoturisteytyshiehojen kasvu- ja teurastulokset roduittain $(\mathrm{ab}=\mathrm{aberdeen}$ angus, ba $=$ blonde d'Aquitaine, ch $=$ charolais, $\mathrm{hf}=$ hereford, $\mathrm{li}=$ limousin, $\mathrm{si}=$ simmental $)$

\begin{tabular}{|c|c|c|c|c|c|c|c|c|c|c|c|c|c|c|c|}
\hline & \multicolumn{7}{|c|}{ Rotu } & \multirow[b]{2}{*}{ SEM $^{1}$} & \multirow[b]{2}{*}{ p-arvo } & \multicolumn{6}{|c|}{ Tilastollinen merkitsevyys $^{2}$} \\
\hline & ayxay & ayxab & ay $\times$ ba & ay $\times$ ch & ayxhf & ayxli & ay $\times$ si & & & $a y \times a b$ & ay $\times$ ba & ay $\times$ ch & ay $\times$ hf & ay $\times$ li & ayxsi \\
\hline Eläinmäärä, kpl & 14221 & 1626 & 1136 & 802 & 487 & 3699 & 827 & & & & & & & & \\
\hline Kasvatusaika, pv & 492 & 478 & 471 & 470 & 477 & 477 & 481 & 3,2 & $<0,001$ & $* * *$ & $* * *$ & $* * *$ & $* * *$ & $* * *$ & $* * *$ \\
\hline Nettokasvu, g/pv & 381 & 443 & 468 & 489 & 458 & 461 & 466 & 3,5 & $<0,001$ & $* * *$ & $* * *$ & $* * *$ & $* * *$ & $* * *$ & $* * *$ \\
\hline Teuraspaino, kg & 202 & 226 & 234 & 242 & 232 & 233 & 237 & 1,8 & $<0,001$ & $* * *$ & $* * *$ & $* * *$ & $* * *$ & $* * *$ & $* * *$ \\
\hline Lihakkuus $^{3}$ & 3,4 & 4,7 & 5,9 & 5,5 & 4,6 & 5,7 & 4,9 & 0,05 & $<0,001$ & $* * *$ & $* * *$ & $* * *$ & $* * *$ & $* * *$ & $* * *$ \\
\hline Rasvaisuus ${ }^{4}$ & 2,7 & 3,6 & 2,5 & 2,9 & 3,8 & 2,9 & 3,1 & 0,04 & $<0,001$ & $* * *$ & $* * *$ & $* * *$ & $* * *$ & $* * *$ & $* * *$ \\
\hline
\end{tabular}

${ }^{1}$ SEM = Keskiarvon keskivirhe.

SEM = Keskiarvon keskivirhe.
${ }_{2}^{2}$ Pareittaiset vertailut on tehty Dunnetin-testillä. Testillä on testattu poikkeaako kyseisen risteytyksen tulos puhtaan ay $\times a y-e l a ̈ i m e n ~ t u l o k s e s t a$.

$* * *(\mathrm{p}<0,001), * *(\mathrm{p}<0,01), *(\mathrm{p}<0,05)$ ja o $(\mathrm{p}<0,10)$.

${ }^{3}$ Lihakkuus: EUROP-luokitus ( 1 = heikoin, 15 = paras). 1=P-, 2=P, 3=P+, 4=O-, 5=O, 6=O+, 7=R-, 8=R, 9=R+, 10=U-, 11=U, 12=U+, 13=E-, 14=E, 15=E+.

${ }^{4}$ Rasvaisuus: EUROP-luokitus ( 1 = rasvaton, $5=$ erittäin rasvainen)

Taulukko 4. Puhtaiden holstein-friisiläishiehojen (fr) sekä fr $\times$ liharoturisteytyshiehojen kasvu- ja teurastulokset roduittain $($ ab $=$ aberdeen angus, ba $=$ blonde d'Aquitaine, $\mathrm{ch}=$ charolais, $\mathrm{hf}=$ hereford, $\mathrm{li}=$ limousin, $\mathrm{si}=$ simmental $)$.

\begin{tabular}{|c|c|c|c|c|c|c|c|c|c|c|c|c|c|c|c|}
\hline & \multicolumn{7}{|c|}{ Rotu } & SEM $^{1}$ & \multicolumn{7}{|c|}{ Tilastollinen merkitsevyys $^{2}$} \\
\hline Kasvatusaika, pv & 486 & 471 & 469 & 464 & 478 & 476 & 473 & 5,2 & $<0,001$ & $* * *$ & $* * *$ & $* * *$ & & $* * *$ & $* * *$ \\
\hline Teuraspaino, kg & 208 & 221 & 238 & 246 & 231 & 237 & 235 & 2,8 & $<0,001$ & $* * *$ & $* * *$ & $* * *$ & $* * *$ & $* * *$ & $* * *$ \\
\hline Lihakkuus $^{3}$ & 3,0 & 4,5 & 5,7 & 5,5 & 4,5 & 5,6 & 4,7 & 0,07 & $<0,001$ & $* * *$ & $* * *$ & $* * *$ & $* * *$ & $* * *$ & $* * *$ \\
\hline Rasvaisuus $^{4}$ & 2,7 & 3,3 & 2,5 & 3,0 & 3,7 & 3,0 & 3,1 & 0,06 & $<0,001$ & $* * *$ & $* * *$ & $* * *$ & $* * *$ & $* * *$ & $* * *$ \\
\hline
\end{tabular}

${ }^{1}$ SEM = Keskiarvon keskivirhe

${ }^{2}$ Pareittaiset vertailut on tehty Dunnetin-testillä. Testillä on testattu poikkeaako kyseisen risteytyksen tulos puhtaan fr $\times f r-e l a ̈ i m e n ~ t u l o k s e s t a$.

$* * *(\mathrm{p}<0,001), * *(\mathrm{p}<0,01), *(\mathrm{p}<0,05)$ ja o $(\mathrm{p}<0,10)$.

${ }^{3}$ Lihakkuus: EUROP-luokitus $(1=$ heikoin, $15=$ paras $) .1=\mathrm{P}-, 2=\mathrm{P}, 3=\mathrm{P}+, 4=\mathrm{O}-, 5=\mathrm{O}, 6=\mathrm{O}+, 7=\mathrm{R}-, 8=\mathrm{R}, 9=\mathrm{R}+, 10=\mathrm{U}-, 11=\mathrm{U}, 12=\mathrm{U}+, 13=\mathrm{E}-, 14=\mathrm{E}, 15=\mathrm{E}+$.

${ }^{4}$ Rasvaisuus: EUROP-luokitus ( 1 = rasvaton, 5 = erittäin rasvainen). 


\section{Yhteenveto ja johtopäätökset}

Ayrshire-rotuiset eläimet luokittuivat lihakkuudeltaan selkeästi paremmin kuin holstein-friisiläisrotuiset sonnit ja hiehot. Ruhojen lihakkuus näytti paranevan liharoturisteytyksen ansiosta enemmän holstein-friisiläis- kuin ayrshire-rodulla.

Liharotusiemennyksillä pystytään tuottamaan puhtaisiin maitorotueläimiin verrattuna paremmin kasvavia ja luokittuvia lihanautoja. Aineiston perusteella limousin on tällä hetkellä eniten käytetty rotu maitotilojen liharotusiemennyksissä. Tämä on tulosten pohjalta varsin perusteltua, sillä limousinristeytyksillä saavutetaan hyvät kasvutulokset ja ruhot luokittuvat hyvin. Myös blonde d'Aquitainerotu sopii erinomaisesti käytettäväksi maitotilojen liharotusiemennyksissä, sillä se on aineiston perusteella selkeästi vähiten rasvoittuva rotu ja myös kasvu- ja lihakkuusominaisuudet ovat risteytyskäytössä hyvät. Niin ikään charolais-risteytysten kasvu- ja teurasominaisuudet osoittautuivat aineistossa hyviksi.

Aineiston tulokset ovat varsin loogisia, sillä ch-, li- ja ba-rodut edustavat tyypillisimmillään ns. pääterotuja, joilla on jo jalostuksellisesti kiinnitetty erityisesti huomiota juuri erinomaiseen teurastulokseen. Keskikokoisten ab- ja hf-rotujen eli ns. emorotujen vahvuudet tulevat selkeimmin esille tarkasteltaessa esimerkiksi emolehmien rehunkäyttökykyä. Naudanlihantuotannon kannalta katsottuna maitotiloilla käytettävien liharoturisteytysten lisäämisen tavoitteena tulisi olla nimenomaan naudanlihantuotannon tehokkuuden ja tuotettavan naudanlihamäärän lisääminen risteytysvasikoiden kautta. Näin ollen juuri pääterotujen käyttö maitotilojen liharotusiemennyksissä on suositeltavaa. Näiden rotujen risteytysvasikoilla voidaan pyrkiä korkeisiin teuraspainoihin yleensä ilman merkittävää riskiä ruhojen rasvoittumisesta ja samalla ruhoille saavutetaan hyvä lihakkuusluokka.

MAILI-hankkeessa tullaan tekemään vuosien 2012-2013 aikana talouslaskelmia, joissa selvitetään maito-liharoturisteytysvasikoiden merkitys lihanautatilan liiketaloudelliseen kannattavuuteen sekä selvitetään liharotusiemennysten merkitys maitotilan liiketaloudelliseen kannattavuuteen. Näiden laskelmien perusteella tullaan saamaan tarkempaa tietoa eri roturisteytysten vaikutuksesta naudanlihantuotantoketjun taloudelliseen tulokseen.

\section{Kirjallisuus}

Herva, T., Virtala, A-M., Huuskonen, A., Saatkamp, H. W. \& Peltoniemi, O. 2009. On-farm welfare and estimated daily carcass gain of slaughtered bulls. Acta Agric. Scand. Sect. A Anim. Sci. 59: 104-120.

Lampinen, A. 1987. Maitorotuisten keinosiemennyssonnien kasvukyky ja sen arvostelu. Kotieläinjalostuksen tiedote nro 76. Helsingin yliopisto/Kotieläintieteen laitos ja Maatalouden tutkimuskeskus/Kotieläinjalostuslaitos. 79 s.

Manninen, M., Huhta, H., Virkajärvi, P., Joki-Tokola, E., Suvitie, M., Puntila, M.-L. \& Röpelinen, A. 1994. Risteytyseläinten ruokinta- ja kasvatuskokeet sekä ruhon ja lihan laatu. Teoksessa: toim. Tarja Korhonen ja Minna Toivonen. Naudanlihantuotannon kehittäminen: Naudanlihantuotannon edistämisprojektin loppuraportti. Helsinki: Maa- ja metsätalousministeriö. s. 35-80.

Ruohomäki, H. 1976. Lihantuotantokokeiden tuloksia. Kotieläinjalostuksen tiedote nro 12. Helsingin yliopisto/Kotieläintieteen laitos ja Maatalouden tutkimuskeskus/Kotieläinjalostuslaitos. $15 \mathrm{~s}$. 